\title{
Diversitas Kapang Serasah Daun Talok (Muntingia calabura L.) Di Kawasan Desa Sukolilo Barat, Kecamatan Labang, Kabupaten Bangkalan, Madura
}

\author{
Arum Krisna Miranti, MG Isworo Rukmi dan Agung Suprihadi \\ Laboratorium Mikrobiologi, Jurusan Biologi FSM Undip \\ E-mail : Arum.krisnaM@gmail.com
}

\begin{abstract}
Leaf litter is one kind of substrate which is good for mold's growth because of its organic matters content particularly cellulose. Research on mold diversity on Talok (Muntingia calabura L.) leaf litter which grow abundance at Sukolilo Barat Village, Labang Subdistrict, Bangkalan, Madura was conducted in order to determined the diversity and to isolate xerophilic mold as well as to examined the enzymatic activity of the isolates. The isolation has been done by direct and indirect method on DG18 agar, MEA, and OA from three samples which is taken purposively. The enzyme activities observed were cellulolytic, amylolitic and proteolytic at $31^{\circ} \mathrm{C}$ temperature. The results showed that 24 isolates found were come from 3 genus i.e. Aspergillus, Curvularia and Fusarium. The Aspergillus was the largest number found. The Shannon-Wiener Index of Diversity showed that the diversity of three leaf litter samples categorized medium. The highest cellulolytic, amylolitic and proteolytic activity at $31^{\circ} \mathrm{C}$ incubation were showed by A. tamarii (ISM 1), A.aculeatus (ISM 10), A. terreus sp. 3 (ISM 17) respectively.
\end{abstract}

Keywords : Diversity, mold, talok litter leaf, Madura

\begin{abstract}
Abstrak
Serasah daun merupakan salah satu substrat yang baik bagi pertumbuhan kapang, karena mengandung berbagai macam bahan organik, terutama selulosa. Penelitian tentang diversitas kapang pada serasah daun Talok (Muntingia calabura L.) yang banyak tumbuh di Desa Sukolilo Barat, Kecamatan Labang, Kabupaten Bangkalan, Madura dilakukan untuk mengetahui keanekaragaman dan mendapatkan kapang xerofilik sekaligus mengetahui aktivitas enzimatis dari isolat kapang yang didapatkan. Isolasi kapang dilakukan dengan metode langsung dan tidak langsung pada media DG18 agar, MEA dan OA dari 3 sampel serasah yang diambil secara purposive. Pengamatan aktivitas ensim dari isolat yang diperoleh juga dilakukan meliputi uji selulolitik, amilolitik dan proteolitik dengan suhu inkubasi $31^{\circ} \mathrm{C}$. Dua puluh empat isolat kapang yang diperoleh dalam penelitian ini terdiri dari 3 genus, Aspergillus, Curvularia dan Fusarium. Kapang Aspergillus merupakan genus yang paling banyak ditemukan. Indeks Keanekaragaman Shannon-Wiener menunjukkan keanekaragaman spesies pada ketiga sampel serasah termasuk sedang. A. tamarii (ISM 1) menunjukkan aktivitas selulolitik tertinggi, A. aculeatus (ISM 10) mempunyai aktivitas amilolitik tertinggi, sedangkan A. terreus sp. 3 (ISM 17) menunjukkan aktivitas proteolitik tertinggi, masing-masing pada suhu inkubasi $31^{\circ} \mathrm{C}$.
\end{abstract}

Kata kunci : Diversitas, kapang, serasah talok, Madura

\section{PENDAHULUAN}

Kapang merupakan jenis fungi multiseluler dan berfilamen atau mempunyai miselium (Samson et al, 2004). Kapang mampu hidup pada suatu lingkungan dengan faktor-faktor yang mempengaruhi pertumbuhannya, yaitu jumlah nutrisi, kelembaban dibawah $90 \%$, suhu $20-30^{\circ} \mathrm{C}$, pH 2,0 - 8,5, dan adanya faktor penghambat misalnya bahan kimia dan antibiotik (Gandjar et al., 2006). Saprofit merupakan sifat kapang tanah yang mendapatkan nutrisi dari benda mati atau sebagai pengurai bahan organik. Salah satu bahan organik yang dapat dijadikan substrat hidup kapang adalah serasah (Waluyo, 2007).

Serasah adalah lapisan tanah bagian atas yang terdiri dari bagian tumbuhan yang telah mati 
seperti guguran daun, ranting dan cabang, bunga dan buah, kulit kayu serta bagian lainnya, yang menyebar di permukaan tanah sebelum bahan tersebut mengalami dekomposisi (Yunasfi, 2006). Pohon talok ( $M$. calabura L.) banyak tumbuh sebagaipohonpeneduh di tepi jalan kawasan Sukolilo Barat, Bangkalan, Madura (Susilawati, 2009).

Wilayah Bangkalan, Madura merupakan daerah yang sebagian besar jenis tanahnya berbahan induk batu kapur, sedangkan sisanya berbahan induk batu pasir dengan $\mathrm{pH}$ diatas 7 . Suhu udara di wilayah Madura berkisar antara 22,5 $-36,2^{\circ} \mathrm{C}$ dengan suhu maksimum mencapai $37^{\circ} \mathrm{C}$ (Hartini et al., 2003). Penyinaran matahari di Madura mencapai $100 \%$ dengan penguapan yang sangat tinggi mencapai $204 \mathrm{~mm}$, sehingga kondisi wilayah tersebut menjadi sangat kering dan gersang (Wahyudi,2009). Kondisi kering tersebut dapat mempengaruhi keanekaragaman flora termasuk mikroflora khususnya kapang. Jenis kapang yang dapat bertahan hidup di daerah ini adalah kapang-kapang xerofilik (Gandjar et al., 2006).

Penelitian mengenai diversitas kapang sangat penting khususnya kapang pada serasah daun, karena melimpahnya keanekaragaman kapang di tanah dan serasah (Bills and Polishook, 1994), sehingga tanah dan serasah dapat menjadi sumber kapang baru yang didapat bisa dimanfaatkan bagi kehidupan manusia di bidang industri, farmasi dan pangan tradisional (Waluyo, 2007).

\section{BAHAN DAN METODE}

Sampel serasah talok (M.calabura L.) diambil secara aseptik dari lokasi yang ditentukan secara purposive di kawasan Desa Sukolilo Barat, Kecamatan Labang, Kabupaten Bangkalan, Madura

Isolasi kapang dilakukan secara langsung dan pengenceran pada medium DG18 agar, MEA, dan oatmeal agar (OA) dengan $\mathrm{pH} 7$, diinkubasi selama 3-7 hari pada $31^{\circ} \mathrm{C}$. Isolat murni dipelihara dalam medium MEA.

Identifikasi kapang dilakukan dengan mencocokkan hasil pengamatan karakteristik morfologi makroskopis dan mikroskopis isolat dengan buku acuan identifikasi kapang.

Uji aktivitas enzim isolat dilakukan untuk aktivitas selulolitik pada medium CMC agar, amilolitik pada Starch Agar dan proteolitik pada skim milk agar.

Perhitungan Indeks Diversitas ShannonWiener (Magurran, 2004):

$\mathrm{H}^{\prime}=$ - Pi ln Pi

$\mathrm{Pi}=\underline{\mathrm{ni}}$

$\mathrm{N}$

Keterangan :

$H^{\prime}=$ Indeks Keanekaragaman Shannon-Wiener

$\mathrm{ni}=$ Jumlah Individu jenis ke- $i$

$\mathrm{N}=$ Jumlah total individu

\section{HASIL DAN PEMBAHASAN}

Kondisi fisik lingkungan pengambilan sampel serasah tertera pada Tabel 1

Tabel 1. Kondisi fisik tanah tempat pengambilan sampel serasah daun talok (M.calabura L.)

\begin{tabular}{cccccc}
\hline Sampel & Kelembaban & $\begin{array}{c}\text { Suhu } \\
\left({ }^{0} \mathrm{C}\right)\end{array}$ & $\mathrm{pH}$ & $\begin{array}{c}\text { Ketinggian }(\mathrm{m} \\
\text { dpl })\end{array}$ & Derajat bujur \\
\hline A & 1 & 31 & 6,7 & 52 & $112^{0} 47^{\prime} 21.2^{\prime \prime}$ \\
B & 1 & 31 & 6,3 & 52 & $112^{0} 47^{\prime} 21.1^{\prime \prime}$ \\
C & 1 & 31 & 6,6 & 52 & $-7^{0} 8{ }^{\prime} 29.081^{\prime \prime}$ \\
\hline
\end{tabular}

Dua puluh empat isolat yang terdiri dari 3 genus, yaitu Aspergillus, Curvularia dan Fusarium berhasil diisolasi dari 3 sampel. Sebagian besar isolat diisolasi dari medium DG18 agar (Tabel 2). Jenis kapang yang paling banyak diisolasi adalah Aspergillus dengan jumlah spesies sebanyak 22 dan terbagi kedalam 6 section yaitu Flavi, Nigri, Circumdati, Terrei, Nidulantes, Fumigati. Kapang Aspergillus bersifat kosmopolit, dapat menghasilkan spora vegetatif (konidia) dan miselium dalam jumlah besar, dan tergolong kapang yang tumbuh cepat (Ilyas, 2007). 
Tabel 2. Jenis Isolat pada 3 Medium Isolasi

\begin{tabular}{|c|c|c|c|c|}
\hline $\begin{array}{l}\text { Kode } \\
\text { Isolat }\end{array}$ & Spesies & DG18 agar & MEA & $\mathbf{O A}$ \\
\hline & $\begin{array}{l}\text { Subgenus Circumdati } \\
\text { Section Flavi }\end{array}$ & & & \\
\hline ISM 1 & A. tamarii & + & - & + \\
\hline ISM 2 & A. parasiticus & + & - & + \\
\hline ISM 3 & A. oryzae & + & + & + \\
\hline ISM 4 & A. flavus 1 & + & + & + \\
\hline ISM 5 & $\begin{array}{l}\text { A. flavus } 2 \\
\text { Section Circumdati }\end{array}$ & + & + & - \\
\hline ISM 6 & A. sclerotiorum & - & + & - \\
\hline ISM 7 & Aspergillus 1 & - & + & - \\
\hline ISM 8 & $\begin{array}{l}\text { Aspergillus } 2 \\
\text { Section Nigri }\end{array}$ & + & - & - \\
\hline ISM 9 & A. japonicus & + & - & - \\
\hline ISM 10 & A. aculeatus & + & - & - \\
\hline ISM 11 & A. niger & + & + & - \\
\hline ISM 12 & A. foetidus & + & + & - \\
\hline ISM 13 & A. tubingensis & + & + & + \\
\hline ISM 14 & $\begin{array}{l}\text { A. awamori } \\
\text { Subgenus Nidulantes } \\
\text { Section Terrei }\end{array}$ & + & + & - \\
\hline ISM 15 & A. terreus 1 & - & + & - \\
\hline ISM 16 & A. terreus 2 & + & - & - \\
\hline ISM 17 & A. terreus 3 & - & + & - \\
\hline ISM 18 & $\begin{array}{l}\text { A. terreus v.ar aureus } \\
\text { Section Nidulantes }\end{array}$ & + & + & - \\
\hline ISM 19 & E. nidulans & + & - & - \\
\hline ISM 20 & $\begin{array}{l}\text { A. nidulans var aeristatus } \\
\text { Subgenus Fumigati } \\
\text { Section Fumigati }\end{array}$ & - & + & - \\
\hline ISM 21 & A. lentulus & + & + & - \\
\hline ISM 22 & $\begin{array}{l}\text { A. fumigatus } \\
\text { Genus Culvularia }\end{array}$ & + & + & - \\
\hline ISM 23 & $\begin{array}{l}\text { Curvularia lunata } \\
\text { Genus Fusarium }\end{array}$ & + & - & + \\
\hline ISM 24 & Fusarium solani & - & + & - \\
\hline & TOTAL & 18 & 16 & 7 \\
\hline
\end{tabular}

Isolat kapang tebanyak diisolasi dari medium DG18 agar (Tabel 2.). Hal ini menunjukkan bahwa sebagian besar kapang merupakan kapang yang bersifat xerofilik, yaitu kapang yang bertahan hidup pada lingkungan yang sangat kering (Gandjar et al., 2006) sesuai dengan kondisi lingkungan Madura yang kering dan gersang (Wahyudi, 2009).

Berbagai jenis kapang dapat diisolasi dari serasah, karena kapang memiliki sifat saprofit dan berperan sebagai pengurai bahan organik (Ilyas,
2007). Kapang saprofit yang terisolasi dari sampel serasah daun talok antara lain genus Aspergillus, Curvularia dan Fusarium. Jenis-jenis kapang ini secara alami banyak ditemukan pada serasah dan berperan besar dalam proses dekomposisi awal serasah daun (Domsch et al., 1980).

Kapang tanah seperti A. flavus 1, A. flavus2, $A$. oryzae, beberapa kelompok $A$. niger, $C$. lunata dan F.solani juga ditemukan pada ketiga sampel serasah (Tabel 4). Kondisi lingkungan seperti suhu, $\mathrm{pH}$, dan kelembaban yang sesuai untuk 
hidup kapang dapat mempengaruhi keberadaan kapang yang ada pada sampel serasah. A.flavus, $A$. flavus 2, A. oryzae, A. niger masing-masing memiliki kisaran suhu optimal $17-42^{\circ} \mathrm{C}$ (Domsch et al., 1980). Suhu lingkungan saat pengambilan sampel adalah $31{ }^{\circ} \mathrm{C}$, sehingga kondisi tersebut sesuai dengan suhu tumbuh ketiga jenis kapang tersebut

Tabel 3. Isolat Kapang dari metode isolasi langsung dan tidak langsung

\begin{tabular}{|c|c|c|c|}
\hline Kode & Spesies & Isolasi Langsung & Isolasi Tidak Langsung \\
\hline & $\begin{array}{l}\text { Subgenus Circumdati } \\
\text { Section Flavi }\end{array}$ & & \\
\hline ISM 1 & A. tamarii & + & - \\
\hline ISM 2 & A. parasiticus & + & - \\
\hline ISM 3 & A. oryzae & + & + \\
\hline ISM 4 & A. flavus 1 & + & + \\
\hline ISM 5 & $\begin{array}{l}\text { A. flavus } 2 \\
\text { Section Circumdati }\end{array}$ & + & + \\
\hline ISM 6 & A. sclerotiorum & - & + \\
\hline ISM 7 & Aspergillus 1 & + & - \\
\hline ISM 8 & $\begin{array}{l}\text { Aspergillus } 2 \\
\text { Section Nigri }\end{array}$ & - & + \\
\hline ISM 9 & A. japonicus & - & + \\
\hline ISM 10 & A. aculeatus & - & + \\
\hline ISM 11 & A. niger & + & + \\
\hline ISM 12 & A. foetidus & + & - \\
\hline ISM 13 & A. tubingensis & + & - \\
\hline ISM 14 & $\begin{array}{l}\text { A. awamori } \\
\text { Subgenus Nidulantes } \\
\text { Section Terrei }\end{array}$ & + & + \\
\hline ISM 15 & A. terreus 1 & + & - \\
\hline ISM 16 & A. terreus 2 & + & - \\
\hline ISM 17 & A. terreus 3 & + & - \\
\hline ISM 18 & $\begin{array}{l}\text { A. terreus var aureus } \\
\text { Section Nidulantes }\end{array}$ & + & - \\
\hline ISM 19 & E. nidulans & + & - \\
\hline ISM 20 & $\begin{array}{l}\text { A. nidulans var aeristatus } \\
\text { Subgenus Fumigati } \\
\text { Section Fumigati }\end{array}$ & + & - \\
\hline ISM 21 & A. lentulus & + & - \\
\hline ISM 22 & $\begin{array}{l}\text { A. fumigatus } \\
\text { Genus Culvularia }\end{array}$ & + & - \\
\hline ISM 23 & $\begin{array}{l}\text { Curvularia lunata } \\
\text { Genus Fusarium }\end{array}$ & - & + \\
\hline ISM 24 & Fusarium solani & - & + \\
\hline & TOTAL & 18 & 11 \\
\hline
\end{tabular}

Ditemukannya kapang-kapang tersebut (Tabel 3) pada ketiga sampel serasah diantaranya karena genus kapang ini memiliki sebaran yang kosmopolit, dan dapat menghasilkan spora vegetatif (konidia) dalam jumlah besar. Kapang ini juga tergolong jenis kapang yang dapat tumbuh dengan cepat. Menurut Kuter (1986) kapang tanah seperti Aspergillus umum ditemukan pada sampel 
serasah daun dan kelompok kapang tersebut sering ditemukan dan diisolasi dengan kelimpahan yang

tinggi pada sampel serasah daun.

Tabel 4. Distribusi kehadiran spesies kapang pada 3 sampel serasah daun talok (M. calabura L.).

\begin{tabular}{|c|c|c|c|c|c|}
\hline \multirow{2}{*}{$\begin{array}{l}\text { Kode } \\
\text { Isolat } \\
\end{array}$} & \multirow{2}{*}{ Spesies } & \multicolumn{3}{|c|}{ Sampel } & \multirow{2}{*}{ Kehadiran (\%) } \\
\hline & & $\mathbf{A}$ & B & $\mathbf{C}$ & \\
\hline ISM 1 & A. tamarii & 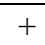 & + & - & 66,67 \\
\hline ISM 2 & A. parasiticus & - & + & - & 33,33 \\
\hline ISM 3 & A. oryzae & + & + & + & 100 \\
\hline ISM 4 & A. flavus sp 1 & + & + & + & 100 \\
\hline ISM 5 & A. flavus sp 2 & + & + & + & 100 \\
\hline ISM 6 & A. sclerotiorum & - & - & + & 33,33 \\
\hline ISM 7 & Aspergillus sp 1 & - & + & - & 33,33 \\
\hline ISM 8 & Aspergillus sp 2 & - & - & + & 33,33 \\
\hline ISM 9 & A. japonicus & - & - & + & 33,33 \\
\hline ISM 10 & A. aculeatus & + & - & - & 33,33 \\
\hline ISM 11 & A. niger & + & + & + & 100 \\
\hline ISM 12 & A. foetidus & - & - & + & 33,33 \\
\hline ISM 13 & A. tubingensis & + & + & + & 100 \\
\hline ISM 14 & A. awamori & + & + & + & 100 \\
\hline ISM 15 & A. terreus $\mathrm{sp} 1$ & + & - & - & 33,33 \\
\hline ISM 16 & A. terreus $\mathrm{sp} 2$ & - & + & - & 33,33 \\
\hline ISM 17 & A. terreus sp 3 & + & - & - & 33,33 \\
\hline ISM 18 & A. terreus var aureus & + & + & - & 66,67 \\
\hline ISM 19 & E. nidulans & + & - & - & 33,33 \\
\hline ISM 20 & A. nidulans var aeristatus & - & + & + & 66,67 \\
\hline ISM 21 & A. lentulus & - & + & + & 66,67 \\
\hline ISM 22 & A. fumigatus & + & - & - & 33,33 \\
\hline ISM 23 & Curvularia lunata & + & + & + & 100 \\
\hline ISM 24 & Fusarium solani & + & + & + & 100 \\
\hline & Jenis Kapang & 15 & 15 & 14 & \\
\hline
\end{tabular}

Ket : A= Plot pengambilan sampel 1

$\mathrm{B}=$ Plot pengambilan sampel 2

$\mathrm{C}=$ Plot pengambilan sampel 3

Dua puluh empat isolat yang diisolasi selanjutnya ditentukan keanekaragamannya dengan menggunakan Indeks Keanekaragaman Shannon-Wiener (Magurran, 2004), Indeks keanekaragaman dari ke 3 sampel tertera pada

Tabel 5, yang menunjukkan bahwa keanekaragaman kapang pada sampel serasah termasuk sedang dan tidak ada dominansi spesies, sehingga ekosistem relatif stabil. 
Tabel 5. Indeks Keanekaragaman (Shanon-Wiener) Kapang Serasah Daun Talok Kawasan Desa Sukolilo Barat, Kecamatan Labang, Kabupaten Bangkalan, Madura.

\begin{tabular}{|c|c|c|c|}
\hline & \multicolumn{3}{|c|}{ SAMPEL } \\
\hline & $\mathbf{A}$ & B & $\mathbf{C}$ \\
\hline Indeks Keanekaragaman (H') & 2,06 & 2,23 & 2,21 \\
\hline Keterangan & $\begin{array}{c}\text { Keanekaragaman } \\
\text { Sedang }\end{array}$ & $\begin{array}{c}\text { Keanekaragaman } \\
\text { Sedang }\end{array}$ & $\begin{array}{c}\text { Keanekaragaman } \\
\text { Sedang }\end{array}$ \\
\hline
\end{tabular}

Hasil uji aktivitas enzimatis isolat-isolat kapang dari serasah daun talok yang meliputi aktivitas selulolitik, amilolitik dan proteolitik terlihat pada Gambar 1. Hampir seluruh isolat menunjukkan aktivitas selulolitik, amilolitik dan proteolitik, hal ini sesuai dengan ciri kapang yang dapat hidup di serasah daun. Kapang yang ditemukan pada serasah sangat berperan menguraikan serasah daun-daunan dalam rentang waktu singkat, karena umumnya kapang saprofit memiliki aktifitas selulolitik (Gandjar et al., 1999).

Aktivitas selulolitik paling tinggi dihasilkan oleh A. tamarii(ISM 1), sedangkan aktivitas amilolitik tertinggi dihasilkan oleh A. aculeatus (ISM 10) dan aktivitas proteolitik tertinggi ditunjukkan oleh A. terreus. 3(ISM 17).
Isolat A. tamarii (ISM 1) merupakan kapang yang dapat menghasilkan enzim selulolitik tertinggi dibandingkan isolat Aspergillus lainnya.

Isolat A. aculeatus (ISM 10) merupakan isolat yang dapat menghasilkan enzim amilolitik tertinggi dibandingkan isolat Aspergillus lainnya. Isolat $A$. aculeatus diketahui dapat menghasilkan enzim amilase, bahkan sudah diproduksi oleh perusahaan Kemin. A produk enzim $\alpha$ amilase dari $A$. aculeatus telah dimanfaatkan untuk enzim tambahan pada makanan ternak (Bedford, 2010).

$$
\text { Isolat A.terreus (ISM 17) dapat }
$$
menunjukkan aktivitas proteolitik yang tinggi. Strain dari species ini diketahui telah dimanfaatkan di industri detergen dan menghasilkan enzim protease tinggi pada kisaran suhu $30-37^{\circ} \mathrm{C}$ (Niyonzima, 2013).

Gambar 1. Grafik aktivitas selulolitik, amilolitik, dan proteolitik isolat kapang yang diisolasi dari serasah daun kersen (M. calabura L.)

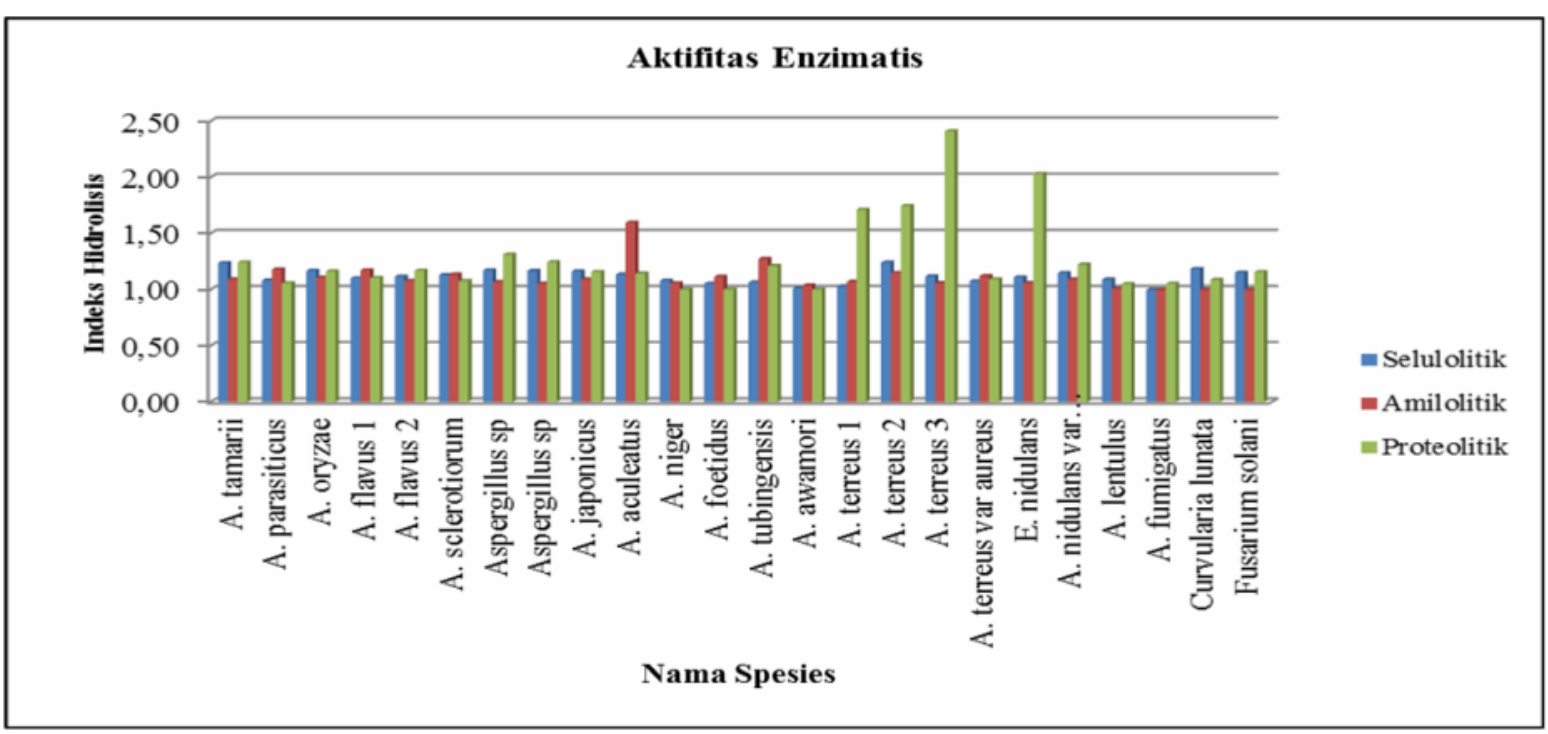




\section{KESIMPULAN}

Berdasarkan hasil penelitian yang telah dilakukan, diperoleh 24 isolat kapang dari serasah daun talok di kawasan Desa Sukolilo Barat, Kecamatan Labang, Kabupaten Bangkalan, Madura yang terdiri dari genus kapang, yaitu: Aspergillus, Curvularia, Fusarium. Kapang Aspergillus merupakan genus yang paling banyak ditemukan. Indeks Keanekaragaman ShannonWiener menunjukkan indeks keanekaragaman species kapang sedang. Berdasarkan Indeks selulolitik, amilolitik dan proteolitik, A. tamarii (ISM1) menunjukkan aktivitas selulolitik tertinggi, A. culeatus (ISM 10) menunjukkan aktivitas enzim amilolitik tertinggi, dan A. terreus 3 (ISM 17) menunjukkan aktivitas enzim proteolitik tertinggi pada suhu inkubasi $31^{\circ} \mathrm{C}$.

\section{DAFTAR PUSTAKA}

Bedford. M. R., G. G. Partridge. 2010. Enzymes in farm animal nutrition, 2nd edition. CABI. London.

Bills, G. F. and J. D. Polishook. 1994. Abundance and diversity of microfungi in leaf litter of lowland rain forest in Costa Rica. Mycologia. 86(2): 187-198.

Domsch, K. H., W. Gams, T. H. Aderson. 1980. Compendium of Soil Fungi. Academic Press. London.

Gandjar. I., R. A. Samson, K. V. D. T. Vermeulen, A. Oetari. dan I. Santoso. 1999. Pengenalan Kapang Tropik Umum. Yayasan Obor Indonesia. Jakarta.

W. Sjamsuridjal, A. Oetari. 2006. Mikologi Dasar dan Terapan. Yayasan Obor Indonesia. Jakarta.

Hartini. S., A. Suprajaka, Rahadiati, G. B. Saputro, \& M. C. Marchiavelli. 2003. Kajian Pulau Madura dan Kepulauan Kengean. Pusat
Survei Sumberdaya Alam Laut-

BAKOSURTANAL. Cibinong.

Ilyas, M. 2007. Isolasi dan Identifikasi Mikoflora Kapang pada Sampel Serasah Daun Tumbuhan di Kawasan Gunung Lawu, Surakarta, Jawa Tengah. Biodiversitas 8 (2): 105-110.

Kuter, G. A. 1986. Microfungal populations assosiated with the decomposition of sugar maple leaf litter. Mycologia. 78: 114-126.

Magurran, A. E. 2004. Measuring Biological Diversity. Blackwell Science Ltd. USA.

Niyonzima, F. N and S. S. More. 2013. Screening and optimization of cultural parameters for an alkaline protease production by Aspergillus terreus $g r$. Under submerged fermentation. Int. J. Pharm. Bio. Sci. 4(1): 1016-1028.

Samson, R. A., E. S. Hoekstra, \& Frisvad. 2004. Introduction to Food Airborne Fungi 7rd ed. Centraalbureau Voor Schimmelcultures. Netherland.

Susilawati. 2009. Pembuatan Pupuk Cair dari Daun dan Buah Kersen dengan Proses Ekstraksi dan Fermentasi. Skripsi. Jurusan Teknik Kimia UPN “Veteran”, Jawa Timur.

Wahyudi, H. 2009. Kondisi dan potensi Dampak Pemanfaatan Air Tanah di Kabupaten Bangkalan. Jurnal Aplikasi: Media Informasi \& Komunikasi Aplikasi Teknik Sipil Terkini 7(1): 14-19.

Waluyo, L. 2007. Mikrobiologi Umum. UMM Press. Malang.

Yunasfi. 2006. Dekomposisi Serasah Daun Avicennia marina oleh Bakteri dan Fungi pada Berbagai Tingkat Salinitas. Disertasi. Program Studi Ilmu Pengetahuan Kehutanan, Institut Pertanian Bogor, Bogor. 